\title{
CURRENT STATUS OF URBAN DRAINAGE SYSTEM AND ITS PROBLEM IN NETROKONA MUNICIPAL, DHAKA
}

Rajon Kanti Datta, Ohidul Alam and Mohammad Mozaffar Hossain

Journal of Institute of Science and Technology

Volume 22, Issue 1, July 2017

ISSN: 2469-9062 (print), 2467-9240 (e)

Editors:

Prof. Dr. Kumar Sapkota

Prof. Dr. Armila Rajbhandari

Assoc. Prof. Dr. Gopi Chandra Kaphle

JIST, 22 (1): 165-178 (2017)

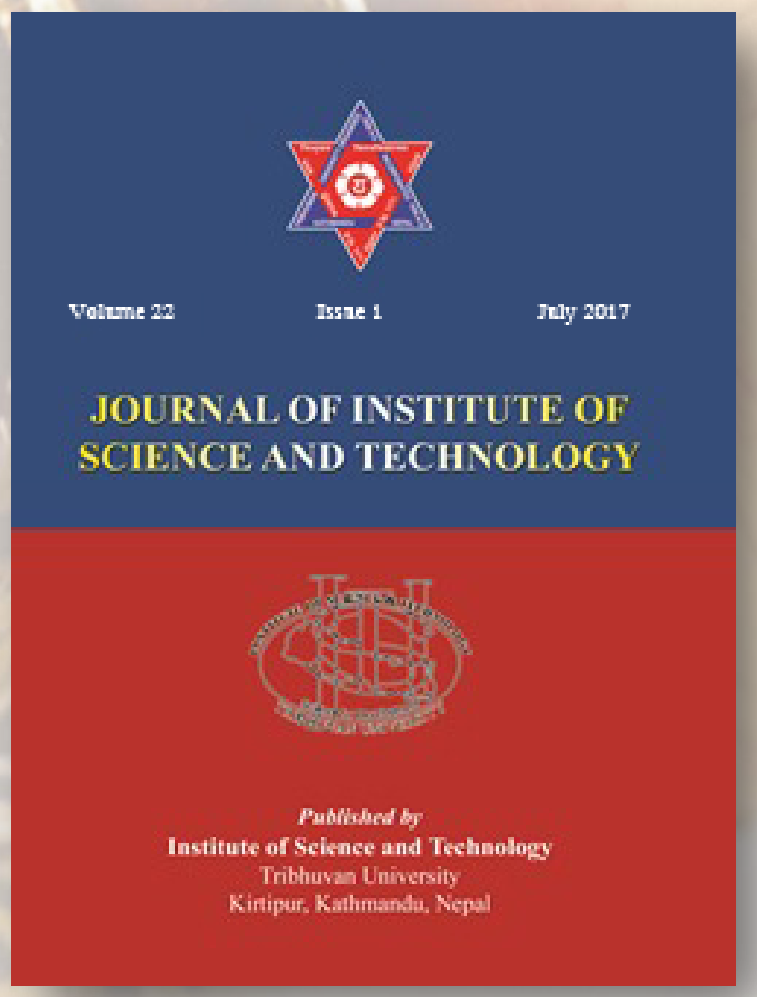

Published by:

Institute of Science and Technology

Tribhuvan University

Kirtipur, Kathmandu, Nepal 


\title{
CURRENT STATUS OF URBAN DRAINAGE SYSTEM AND ITS PROBLEM IN NETROKONA MUNICIPAL, DHAKA
}

\author{
Rajon Kanti Datta ${ }^{1}$, Ohidul Alam ${ }^{2 *}$ and Mohammad Mozaffar Hossain ${ }^{1}$ \\ ${ }^{1}$ Institute of Forestry and Environmental Sciences (IFES), University of Chittagong, \\ Chittagong - 4331, Bangladesh \\ ${ }^{2}$ School of Resources and Environmental Engineering, East China University of Science and \\ Technology (ECUST), Shanghai - 200237, China \\ *Corresponding E-mail: ohid776@gmail.com
}

\begin{abstract}
Rapid and haphazard urbanization has triggered environmental hazards in Bangladesh. Analogously, Netrokona Municipal is also facing problems due to unplanned and unstable urban infrastructural development. The quest of the study was to explore the status of current urban drainage system and its problem. Therefore, a preliminary reconnaissance survey was accomplished in the study area and then a semi-structured questionnaire was designed. By adopting simple random sampling method, the study area was surveyed covering 50 respondents in different wards to collect primary data. Results revealed that poor drainage system (PDS) is one of the most liable factors for environmental deterioration. The maximum urban drainage system was found unclosed with number of 49 (i.e., 98\%). It was 34 drains were made of brick, while 17 were worst type, 32 had odor problem, 20 were not well designed, 29 had inadequacy of drains, 18 with poor technical fitness, 22 wastes disposal in gutters, 18 had clogging of ditches \& drains, and 15 with broken road surface respectively. The consequent major environmental and health problems were flash-flooding $(42 \%)$, and skin disease (38\%) respectively. In case of public opinion, the highest percentage (i.e., 30\%) suggested to stoutly prohibit dumping of garbage into gutters. PDS was found strongly positive correlated with its effects on environment $(\mathrm{r}=0.98)$ and on public health $(\mathrm{r}=0.91)$. Thereby, present PDS affects the environment as-well-as public health by enhancing frequent flash-floods and spreading diseases within the study area.
\end{abstract}

Key words: Adaptability, Climate Change, Drainage System, Municipal, Problems.

\section{INTRODUCTION}

Drainage is an integral part of different areas or environment (e.g. urban, rural, forest, and agricultural etc.) to remove unwanted water volume (Parkinson, 2003; Mcdonough \& Braungart, 2002). It can be defined as the natural or artificial way used to remove unwanted or excess water from any surface or sub-surface area (Coterell, 1980; Alberta Environment, 1999). Here, urban drainage includes the removal of unexpected water from urban areas (i.e., domestic and industrial wastewater) along with sewerage, grey-water, heavy rainfall, and stormwater (Laskar, 1996; Mc Inerney \& Magar, 2014). Inversely, most of the drainages in the rural areas are related to road drainage that is designed to shed water into roadside ditches. Such drainages are susceptible to cause erosion and ultimate results of which are the sedimentation problems in nearby water bodies (Pidwirny, 2006). Urban environment is more compacted and densely populated compared to other areas. Therefore, a well-designed and spacious drainage system is necessary for the urban areas to remove unwanted water volume (APWA, 1976; Ahmed \& Islam, 2014). Poor and inadequate drainage system blocks normal water flow and creates water logging and flash-floods during heavy rainfall and natural calamities. Thereby, appropriate drainage system is very important for safe and sustainable urban environment (Kirby \& Laurson, 1932). All cities and towns have their own urban drainage system (UDS) with developed countries having well-designed UDS adaptive to climate change situation (i.e. heavy rainfall and flood). But UDS is poor in quality and incapable to remove sudden extensive water flow in developing countries (Burian, 2001; Bishop, 1968).

Bangladesh is one of the most densely populated developing countries along with limited land areas. 
Therefore, most of its drainage facilities are not well-structured and poor in quality which is liable to water logging and flash-flood (Khan et al., 2012; Tawhid, 2004; Jahan, 2012). Amidst numerous influencing factors, rapid and random urbanization is the predominant cause accelerating such environmental hazards. The present urban population rate is $29.4 \%$ including $3 \%$ annual growth (BBS, 2011; Ahmed \& Islam, 2014). The size of urban area has increased from 11-34\% between 1960 and 2005 in Dhaka City. But geomorphologic and hydrologically, Dhaka City is highly vulnerable to seasonal inundations like many other cities in Asia (Taleb, 2012; Huq \& Alam, 2003; Apirumanekul \& Mark, 2001). Consequently, it faces extensive water logging problems during the monsoon as a regular phenomenon in recent years. Unfortunately, the situation was highlighted in September 1996 in Dhaka City; when, people realized ankle-to-knee deep water on the streets (Apirumanekul \& Mark, 2001). Such water logging problem can be mitigated by designing UDS that is responsive to the geo-climate and hydrological characteristics of that place (Mowla \& Islam, 2013; Chowdhury \& Islam, 2005). Besides, there are many factors that block drainage system viz. inadequate sections, low capacity \& gravity, natural siltation, absence of inlets \& outlets, and lack of proper maintenance etc. (Alom \& Khan, 2014; Bari \& Hasan, 2001). Thus, both engineered infrastructures and non-structural approaches are important to prevent and mitigate problems related to flooding and deterioration in urban environment (Parkinson, 2003; Islam, 1999).

There is a high probability of Bangladesh being heavily affected by climate change induced impacts (i.e., heavy rainfall and flooding) due to its geographic location (ADB 2011, Rana 2011). Similarly, urban growth is increasing in coastal zones of Bangladesh where UDS suffers additional stresses. Therefore, urban drainage quality and its performance are important in the coastal towns (Paul et al., 2013; Shamsuddoha \& Chowdhury, 2007). The cities in coastal belt are particularly vulnerable to climate change induced impacts (Khan et al., 2012). Hence, the timely implementation of capacity development technical assistance to assess the impacts of climate change as well as to explore adaptation options is regarded as important to minimize the development project impacts in the coastal towns (ADB, 2011; Paul et al., 2013).
Rapid and indiscriminate urbanization is also occurring in Netrokona Municipal as other cities in terms of infrastructural development and urban expansion. Poor drainage system (PDS) is one of the responsible factors that have made all development activities and environment unsustainable in Netrokona Municipal (LGED, 2015; Ashraf \& Chowdhury, 2009). Among numerous problems, flash-floods and permanent flooding has mostly damaged properties of the people owing to the topography of Netrokona Municipal (Apirumanekul \& Mark, 2001; Mowla \& Islam, 2013). Since it is known as an erosion level zone over the years, during heavy rainfall and flooding, many problems occurred such as; flooding of houses, poor accessibility, distortion of the environmental beauty, and neatness through the deposition of wastes carried by running water, destruction of infrastructural facilities, and sedimentation in the adjacent water bodies (ShakirR-Rahi, 2011; BBS, 2013). In addition, inadequate number of drainage channels is also a problem of serious concern in the urban area. Thereby, the study was accomplished to investigate present UDS of Netrokona Municipal and its adverse impacts on environment and public health from October, 2012 to August, 2013. The findings of the study will facilitate the policy makers and local government to take necessary initiatives to mitigate unexpected adverse impacts due to PDS.

\section{MATERIALS AND METHODS}

\section{Overview of the study area}

Netrokona subdivision was established in 1882 which was turned into district in 1984. It is situated between $24^{\circ} 35^{\prime}$ and $25^{\circ} 15^{\prime} \mathrm{N}$ Latitude, and between $90^{\circ} 30^{\prime}$ and $91^{\circ} 15^{\prime}$ E Longitude (Figure 1). Its total area is 2810.40 square kilometers. Average annual maximum temperature is $33.3^{\circ} \mathrm{C}$ and minimum $12^{\circ} \mathrm{C}$, while total rainfall is $2174 \mathrm{~mm}$ (Banglapedia, 2006). Its total population is 1.94 million where majority percentage (i.e., $83 \%$ ) is Muslim and the average literacy rate is $26 \%$. There are five municipalities in Netrokona districts (Sarkar, 2012). Amidst, Netrokona Municipal is located at the center of Netrokona district. It is one of the A-class category municipals in Bangladesh. It consists of 9 wards along with an area of 13.63 square kilometers. Its total population is 53,853 (i.e., Muslim $89.32 \%$ ), density is 3951 per square kilometer and literacy rate is $54.2 \%$. 


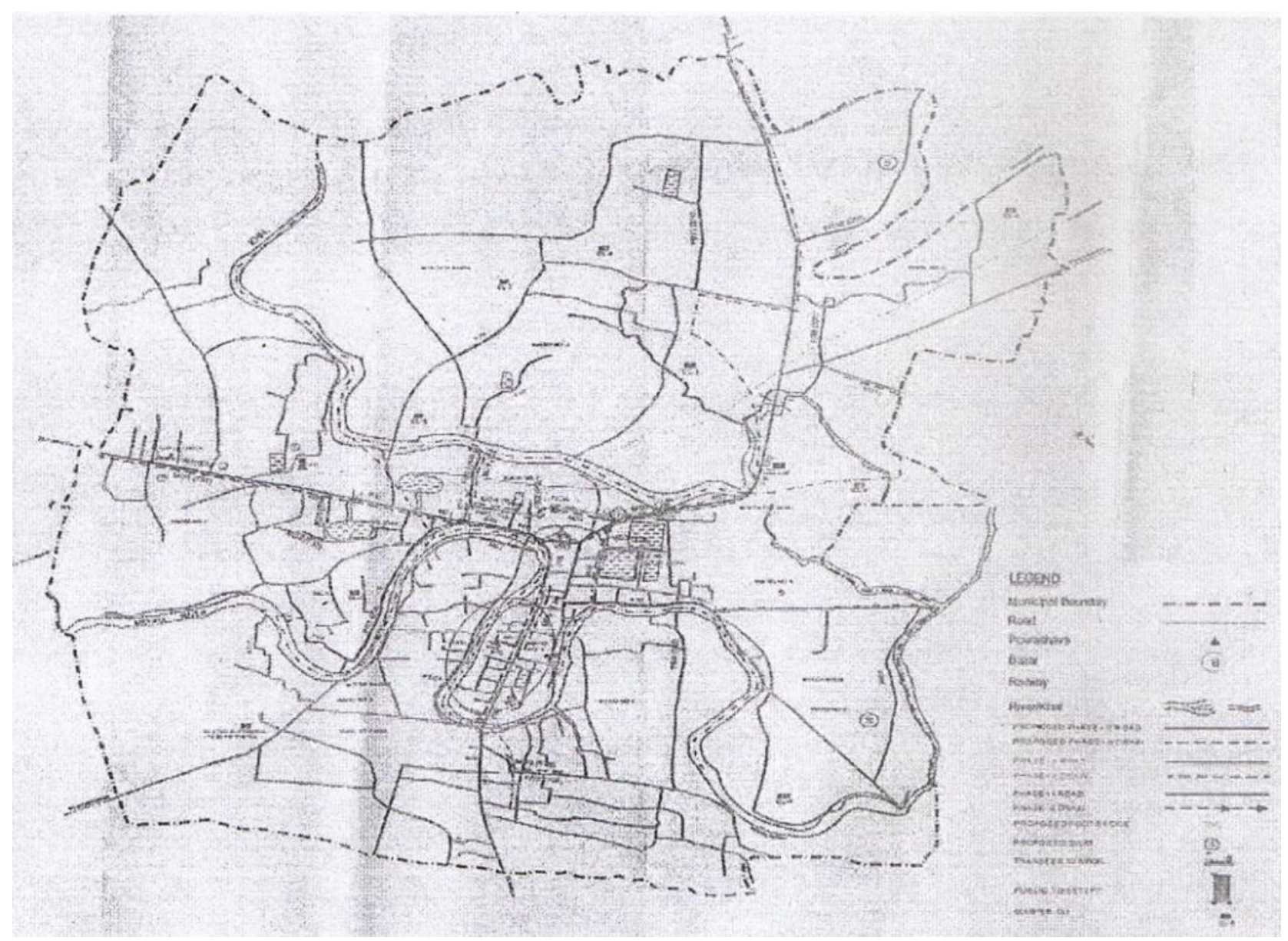

Fig. 1. Drainage map of Netrokona Municipal (Source: UPDD).

\section{Questionnaire preparation}

To collect baseline information about UDS of Netrokona Municipal, we communicated with chief engineer of Urban Planning and Development Department (UPDD) and a critical review was conducted very carefully on the available literatures both in published and unpublished sources. Then a reconnaissance empirical field survey was conducted to observe current drainage situation of Netrokona Municipal. Based on gathered experiences from reconnaissance survey, a semi-structured questionnaire was designed.

\section{Questionnaire survey and data collection}

Simple random sampling method was followed to conduct questionnaire survey in the study area. From each ward, 5 to 6 persons were randomly selected to survey questionnaire. A total of 50 questionnaires were surveyed amongst 50 respondents in the study area. Further, several research tools were used to collect field level data and experience of city dwellers namely; direct field observation, oral interviews, and group discussions. In addition, interviews and group discussions were also arranged with the concerned officers of UPDD and Conservancy Department aiming to collect original data.

\section{Basic information of the respondents}

Among 50 respondents, the mean age of the respondents was 37.64 years and standard deviation is 9.16 years where the maximum age is 57 year and minimum 24 year. Here, 32 respondents were Muslims (62\%) and 18 Hindu (36\%) including 43 male $(86 \%)$ and 7 female (14\%). In case of education, 3 persons completed primary level and 9 S. S. C., 9 H. S. C., 23 graduate (i.e., 46\%) and 6 postgraduate levels. Besides, it was seen that different person are involved in diverse occupation and amidst 50 respondents -4 households, 22 businessmen (i.e., 44\%), 1 transport \& communication, 12 government service holders and 10 private service holders were found. 
Table 1. Location area of surveyed respondents in Netrokona Municipal.

\begin{tabular}{|l|l|}
\hline Name of area & $\begin{array}{l}\text { Respondents } \\
\text { number }\end{array}$ \\
\hline Joynagar & 6 \\
\hline Kathli & 3 \\
\hline North Satpai & 2 \\
\hline South Satpai & 3 \\
\hline Kurpar & 4 \\
\hline Station Road & 2 \\
\hline Kali Bari Road & 3 \\
\hline Nagra & 3 \\
\hline Tari Bazar & 2 \\
\hline Muktar Para & 4 \\
\hline Bonbibhag & 2 \\
\hline Boro Bazar & 4 \\
\hline Choto Bazar & 5 \\
\hline Ukil Para & 5 \\
\hline Ananda Bazar & 2 \\
\hline
\end{tabular}

\section{Data analysis}

The collected data from field survey was compiled in MS-Excel sheet and then made re-arrangement according to questionnaire survey and personal observations. Later, all data was analyzed by using MS-Excel sheet (version: 2010) and Statistical Package for Social Science (SPSS) (version: 18) for creating required graphs and statistical analysis (e.g., average mean, standard deviation, \& simple correlation).

\section{RESULTS}

Quality of present drainage system and problems

Infrastructure development and quality of Netrokona Municipal is not similar to major cities of Bangladesh (e.g., Dhaka, Chittagong, and Khulna). But it is important for sustainable environment and development to ensure safe life of city dwellers. Majority number of the existing drains within the study area are unclosed drainage system (i.e., 98\%) while $2 \%$ are closed drainage system (Table 2). This indicates the more probability of pollution (air, water, soil) and public health risks associated with present drainage system. Though urban areas in the world have their own UDS, developing countries have more problems compared to developed countries (Burian, 2001; Bishop, 1968). Further, poor and narrow drainage system blocks normal water flow and creates water logging as well as flash-floods during heavy rainfall, and natural calamities. Therefore, an appropriate drainage system is very important for safe and sustainable urban environment and development (Kirby \& Laurson, 1932).

Similarly, different types of construction materials were used in constructed UDSs of Netrokona Municipal. But the quality of existing drains construction materials are not good compared to developed countries and major cities in Bangladesh. The collected data about used construction materials for current UDSs are shown in details (Table 2). Here, it was found that the highest numbers of drains in the study area were constructed by using bricks(i.e., 68\%) followed by concrete (18\%), and 14\% kacha (mud). But none of the drains were found have been constructed using either steel, plastic or any other materials as construction materials. Most of the drainage facilities in Bangladesh are not constructed using high quality and durable materials (Khan et al., 2012; Tawhid, 2004).

Table 2. Different types of drainage system and used construction materials.

\begin{tabular}{lll}
\hline \multicolumn{2}{l}{ Drainage system } \\
\hline Types & Frequency & Percentage (\%) \\
\hline Closed & 1 & 2 \\
\hline Unclosed & 49 & 98 \\
\hline Total & 50 & 100 \\
\hline Construction & materials & \\
\hline Brick & 34 & 68 \\
\hline Concrete & 9 & 18 \\
\hline Steel & 0 & 0 \\
\hline Plastic & 0 & 0 \\
\hline Kacha (mud) & 7 & 14 \\
\hline Others & 0 & 0 \\
\hline Total & 50 & 100 \\
\hline
\end{tabular}

The current status of constructed UDS in Netrokona Municipal area is not at satisfactory level. The collected and observed data from field is presented in (Table 3). Here, six satisfactory levels were identified 
to determine the condition of existing drainage services within the study area based on performances and strength of drains. It was found that most of the drains condition were worst type (i.e., 34\%), followed by $30 \%$ worse, $22 \%$ bad, and $14 \%$ good drainage condition respectively. Therefore, both engineered infrastructures and non-structural approaches are needed to improve existing UDS and to reduce related problems considering geographical location (Parkinson, 2003; Islam, 2003).

Similarly, the quality of the present drainage facilities is not good. Therefore, drainage facilities related data was also collected from the study area to ascertain the quality of existing UDS. The collected data are presented in (Table 3). Here, $40 \%$ of the UDS was found not well designed, $22 \%$ highly fractured, $18 \%$ very narrow gutters, and not $20 \%$ well-plastered gutters in Netrokona Municipal. In general, the quality of drainage facilities in Netrokona Municipal was found to be poor in quality. Hence, there is need to improve the existing PDS with-a-view-to provide a better environment for city dwellers as-well-as ensure sustainable development.

Table 3. Present status and facilities of drainage system in Netrokona Municipal.

\begin{tabular}{lll}
\hline \multicolumn{2}{l}{ Status of drainage system } & \\
\hline Condition & Frequency & Percentage (\%) \\
\hline Best & 0 & 0 \\
\hline Better & 0 & 0 \\
\hline Good & 7 & 14 \\
\hline Bad & 11 & 22 \\
\hline Worse & 15 & 30 \\
\hline Worst & 17 & 34 \\
\hline Total & 50 & 100 \\
\hline Drainage facilities & \\
\hline Very narrow & 9 & 18 \\
\hline Not well design & 20 & 40 \\
\hline Not well plastered & 10 & 20 \\
\hline Highly fractured & 11 & 22 \\
\hline Not present at all & 0 & 0 \\
\hline Total & 50 & 100 \\
\hline
\end{tabular}

Poor quality of UDS of Netrokona Municipal creates enormous environmental problems and public health hazards. So, the collected data about city dwellers facing odors problem due to PDS is shown in (Figure 2). The reasons for creating bad odor problems were extensive dumping of garbage into drainage flow and illegal construction on drains which ultimately blocks normal drainage flow and enhances decomposition of locked garbage. It was observed that, a large number of UDS in Netrokona Municipal were liable to odor problem which was agreed by $64 \%$ people while $36 \%$ disagreed. Thus, the current UDS in Netrokona Municipal is not good for sustainable environment from public health aspect. The impact of PDS is diverse in the urban areas such as sociocultural, health, economic, and environmental (Jahan, 2012). Odor problems due to PDS create problems, especially for passersby and nearby city dwellers in the urban areas.

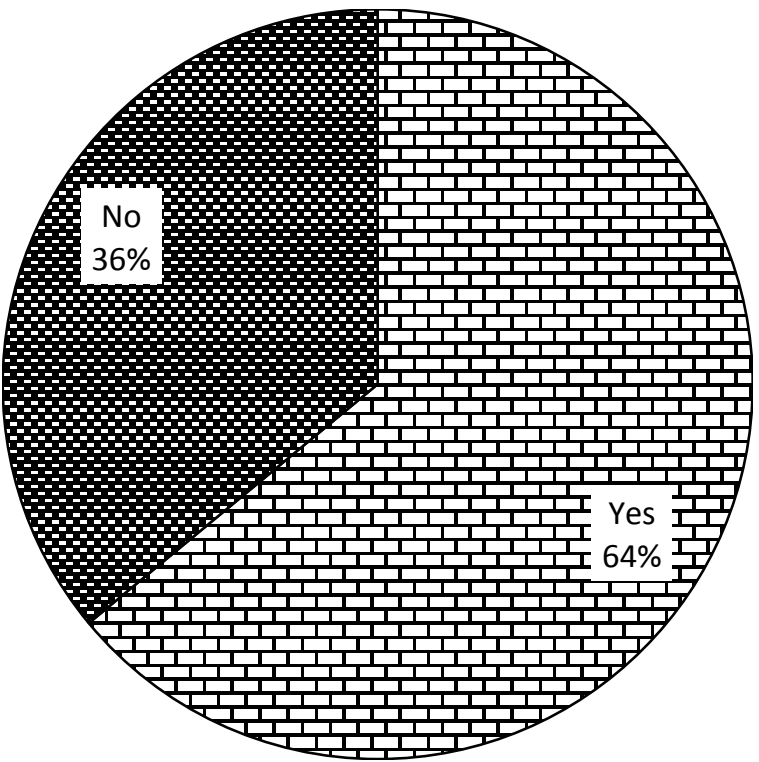

Fig. 2. Percentage of odor problems faced by city dwellers due to PDS.

\section{Causes of inadequacy of drainage system}

Fast and indiscriminate urbanization in Netrokona Municipal, has made congested urban areas and resulted in deterioration of drains quality (LGED, 2015; Ashraf \& Chowdhury, 2009). Inadequacy of UDS is liable for flash-floods; therefore, adequacy of drainage system was studied. The collected data related to the assessment of the adequacy of current UDS of Netrokona Municipal was analyzed. Results show that the existing drainage systems in Netrokona Municipal were inadequate $58 \%$ by positive and $42 \%$ by negative according to respondents. However, 
inadequacy of the drains was measured by considering total number of drains in the municipal along with width and water carrying capacity.

In other words, the major causes of inadequacy of present drainage systems in Netrokona Municipal based on survey data analysis are presented in (Table 4). It was found that the major causes of in adequacy of UDS in Netrokona Municipal were poor technical fitness $36 \%$, lack of information \& communication $14 \%$, and government negligence $12 \%$ respectively. Inversely, other causes were poor monitoring \& evaluation by $12 \%$ and inadequate funding by $16 \%$ respectively. In addition, it was seen to be causative factors of inadequacy of drainage systems in Netrokona Municipal combined of inadequate funding, government negligence, poor technical fitness, poor monitoring and lack of information by $10 \%$. Therefore, the current UDS is accountable for creating environmental and public health hazards in Netrokona Municipal. Alom \& Khan (2014) found that inadequate and conventional drainage system with low capacity \& gravity, natural siltation, absence of inlets \& outlets, and lack of proper maintenance are the prime causes of blockage in drainage system.

Table 4. The causes of inadequacy of drainage system in Netrokona Municipal.

\begin{tabular}{lll}
\hline Major causes & Frequency & Percentage (\%) \\
\hline Inadequate funding & 8 & 16 \\
\hline Government negligence & 6 & 12 \\
\hline Poor technical fitness & 18 & 36 \\
\hline Poor monitoring & 6 & 12 \\
\hline Lack of information and communication & 7 & 14 \\
\hline All of the above & 5 & 10 \\
\hline Total & $\mathbf{5 0}$ & $\mathbf{1 0 0}$ \\
\hline
\end{tabular}

\section{Major causes of PDS and its environmental impacts}

There are several causes for PDS in Netrokona Municipal among them major causes were focused in the study. From Table 5, it is seen that the prime cause of PDS was the wastes disposal into gutters (i.e., 44\%) which impedimented and blocked the running water. Further, the gutters of $20 \%$ drainages were not wide enough to accommodate the volume of flow. Similarly, poor drainage connectivity, substandard materials for construction, and combined of wastes disposal into gutters, not enough wide drainage, poor drainage connectivity and use of sub-standard materials causes of PDS were identified to be $14 \%, 12 \%$ and $10 \%$ respectively in Netrokona Municipal. Consequently, the major causes of PDS shown in Table 4 should be improved immediately. Such PDS is not adaptable to climate change induced situation rather it creates environmental and health hazards (Alam et al., 2013). Asaduzzaman et al. (2014) found that the problems of solid wastes and drainage congestion in the residential areas have become a major concern of the Dhaka city. Solid waste disposal, drainage facilities, and water logging scenario are worse at Shakari Bazar and Mirpur Pallabi.

PDS was responsible for many adverse effects and the major ones are shown in (Table 5). Here, the clogging of ditches and drains due to illegal throwing or dumping of solid wastes was found as the main effect (i.e., 36\%). Further, clogging of ditches and drains creates impediment for running water in drainage flow. Similarly, it causes environmental pollution such as water, soil and air. It is also liable for urban flash-flood that accelerate blockage of drainage flow. The other main adverse effects are - the drain water come up over the road surface $32 \%$, drain water flow disrupted $4 \%$, and together - clogging of ditches \& drains, drain water flow disrupted and drain water come up over surface $16 \%$ respectively in Netrokona Municipal. Thereby, the present UDS of Netrokona Municipal is not environment friendly, rather threat for environment and public health. Unplanned distribution of solid wastes generation sources and unfair disposal of wastes create numerous problems for UDS (Hossain et al., 2013). Another study found that most roads in Khartoum state (Sudan) suffered from PDS which causes severe distresses and damages of pavement (Zumrawi, 2014). 
Table 5. Major causes of PDS and its adverse effects for wastes.

\begin{tabular}{lll}
\hline Poor drainage system & Frequency & Percentage (\%) \\
\hline Major cause & 22 & 44 \\
\hline Wastes disposal into gutters & 10 & 20 \\
\hline Not enough wide drainage & 7 & 14 \\
\hline Poor drainage connectivity & 6 & 12 \\
\hline Use of sub-standard materials & 5 & 10 \\
\hline All of the above & 50 & 100 \\
\hline Total & & 36 \\
\hline Environmental impact & 18 & 12 \\
\hline Clogging of ditches and drains & 6 & 32 \\
\hline Drain water flow disrupted & 16 & 16 \\
\hline Drain water come up over surface & 8 & 4 \\
\hline All of the above & 2 & $\mathbf{1 0 0}$ \\
\hline Others & $\mathbf{5 0}$ & \\
\hline Total & &
\end{tabular}

The causes of disrupted transport system in Netrokona Municipal due to PDS based on survey are presented in (Figure 3). It was found that the major causes of disruption of transportation system due to PDS were the breakdown of road surface $30 \%$, flash-flood $26 \%$, water logging $20 \%$, reduced life-span-of road $12 \%$, all of the above (combined) $8 \%$ and others $4 \%$. During the heavy rainfall and flood, the transport systems of Netrokona Municipal become worse resulting in environmental deterioration and public health hazards. PDS also causes early pavement distresses leading to driving problems and structural failures of road. To prevent or minimize premature pavement failures and to enhance the road performance, it is necessary to provide an adequate and welldesigned drainage (Zumrawi, 2014).

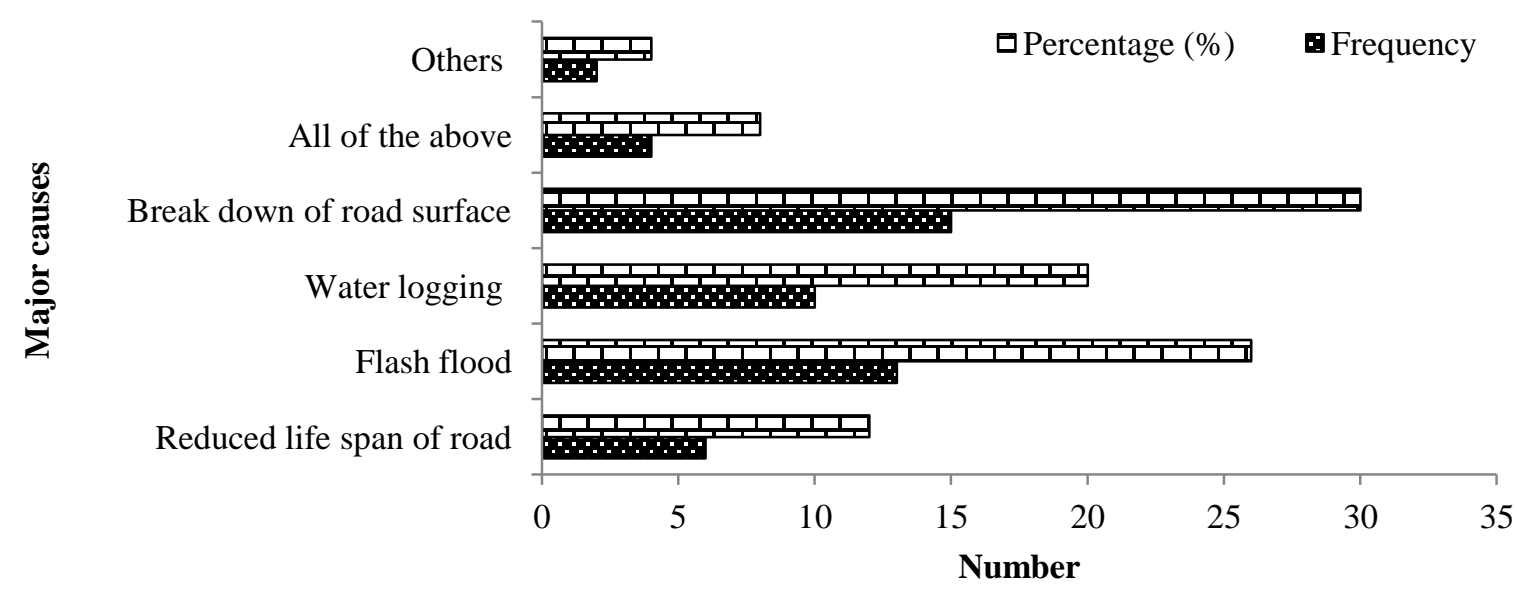

Fig. 3. Causes of disrupted transportation system due to PDS.

Environmental and infrastructural implication due to PDS

Like other problems, PDS has also created environmental and infrastructural complication in
Netrokona Municipal. Table 6 shows that the main environmental problem due to PDS is flooding which accounts for $42 \%$. Other environmental problems were - soil erosion $20 \%$, distortion of 
aesthetic environment $10 \%$, deposition of debris $8 \%$, bringing in siltation of streams $4 \%$, other problems $4 \%$, and all of the above (combined) $12 \%$ respectively. In such a way, the existing PDS plays an extensive adverse effect on the overall environment and development of the study area as well as threat for its sustainability. A report found that urban design and planning that is responsive to the geo-climate and hydrological characteristics of the place can help to mitigate water logging problem in Dhaka city (Mowla \& Islam, 2013). The expected effects of climate change necessitate a change in the approach used to plan and design drainage infrastructure. The planning and designing of new drainage infrastructure should incorporate development features and sustainable UDS that provide multiple benefits. Modifications of existing drainage infrastructure, is complicated by the integration of the minor UDS with other infrastructure and a lack of space for the construction (Arisz \& Burrel, 2006).

Similarly, the traditional and PDS of Netrokona
Municipal is responsible for spreading diseases among city dwellers (Table 6). It was found that disease occurred due to PDS is a big public health problem. From (Table 6), it is observed that skin disease was the main health problem in the study area (i.e., 38\%). Other health problems faced by city dwellers were diarrhea (24\%), cholera (12\%), fever (6\%), typhoid (4\%), all of the above (combined) 6\%, and others 6\% .The storm water in urban areas becomes polluted as it mixes with solid waste, clinical waste, silt, contaminants, domestic wastes and other human activities that increase the water borne diseases. The stagnant storm water leads to the creation of breeding sites for diseases vectors (Tawhid, 2004). The urban environment involves health hazards with an inequitable distribution of exposures and vulnerabilities. The high population density in many poor urban areas means that interventions at a small scale level can assist many people, and existing infrastructure can sometimes be upgraded to meet health demands (Kjellstrom et al., 2007).

Table 6. The environmental and health effects occurred due PDS.

Environmental effects

\begin{tabular}{lll}
\hline & Frequency & Percentage (\%) \\
\hline Flooding & 21 & 42 \\
\hline Erosion & 10 & 20 \\
\hline Siting of streams & 2 & 4 \\
\hline Deposition of debris & 4 & 10 \\
\hline Distortion of asthetic environment & 5 & 12 \\
\hline All of the above & 6 & 4 \\
\hline Others & 2 & $\mathbf{1 0 0}$ \\
\hline Total & $\mathbf{5 0}$ & 12 \\
\hline Health effects (diseases) & & 24 \\
\hline Cholera & 6 & 6 \\
\hline Diarrhoea & 12 & 4 \\
\hline Fever & 3 & 38 \\
\hline Typhoid & 2 & 4 \\
\hline Skin disease & 19 & 0 \\
\hline Dengue fever & 2 & 6 \\
\hline Small pox & 0 & 6 \\
\hline All of the above & 3 & $\mathbf{1 0 0}$ \\
\hline Others & 3 & $\mathbf{5 0}$ \\
\hline Total & &
\end{tabular}


Public opinions to resolve associated problems with PDS

City dwellers have been living in the municipal area for long time. Therefore, they practically know well about the actual causes of existing PDS along with associated environmental and health risks. They tried cope with adverse situation and thus adopted with it too. So public opinions or suggestions were focused in the questionnaire and collected related data during survey. From (Figure 4), it is seen that the dumping of refuse into gutters should be strongly prohibited, which will be the main solution according to respondents (i.e., 30\%). Similarly, the other suggestions were from city dwellers were - proper drainage systems should be ensured by $20 \%$; the width, length \& depth of drainage systems should be expanded by $18 \%$; the use of standard \& quality materials in the construction of drainage facilities should be encouraged by 14\%; large drainages system should be provided by $12 \%$; and the drainage systems should be properly channeled by $6 \%$. According to city dwellers' response, people are aware of problems faced daily due to PDS and are interested to support city authority to overcome such problems to ensure safe and sound city environment.

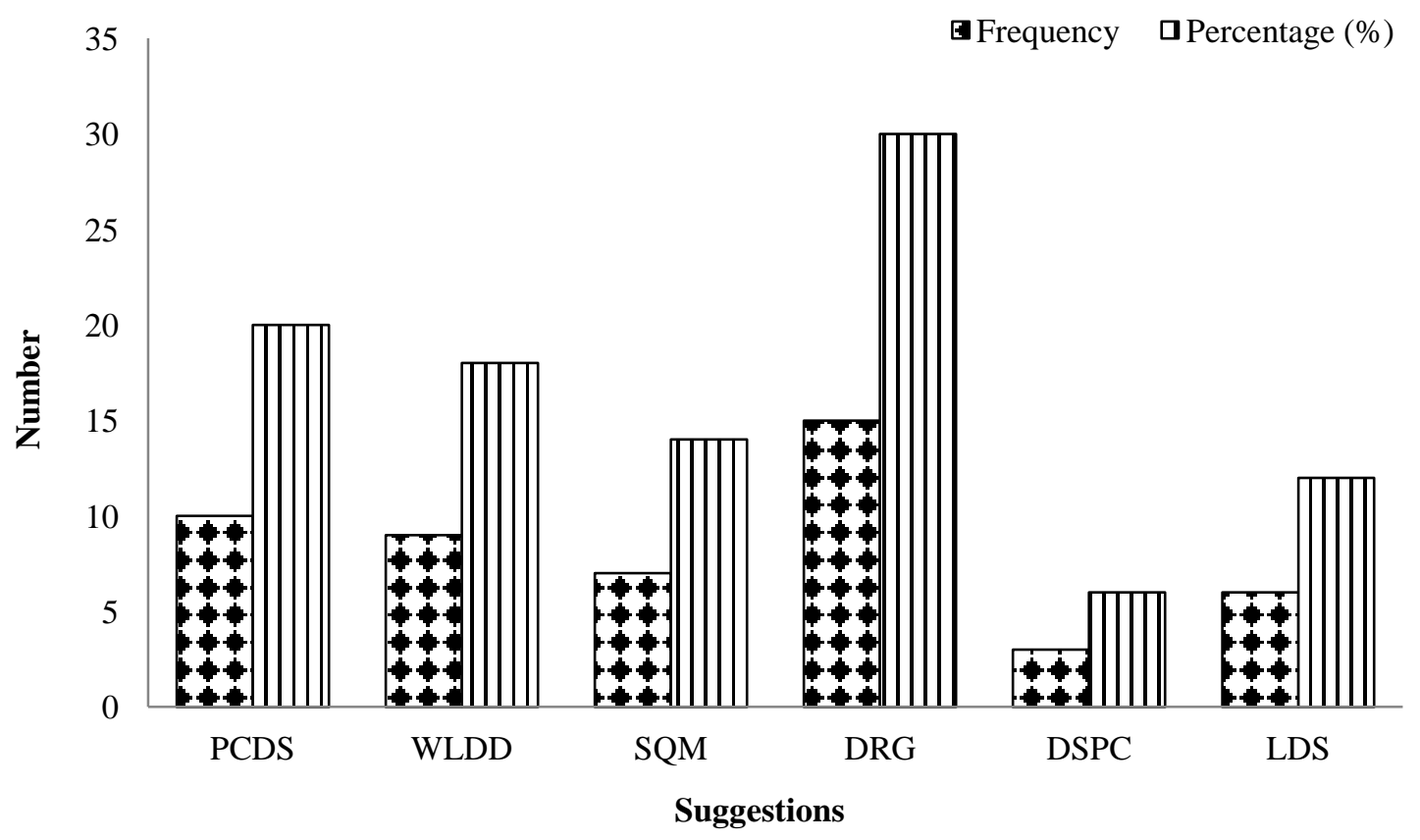

Fig. 4. Suggestion for solving existing drainage system's problem.

N.B.: PCDS $=$ Proper connectivity of the drainage systems should be ensured, WLDD = Width, length and depth of drainage systems should be expanded, $\mathrm{SQM}=$ Use of standard and quality materials in the construction of drainage facilities should be encouraged, DRG = Dumping of refuse in gutters should be strongly prohibited, DSPC = Drainage systems should be properly channeled, and LDS = Large drainages system should be provided.

Correlation between PDS and effects on environment/health

The relation between major causes of PDS and its consequent effects on the environment is stated (Table 7). PDS has significantly influenced environmental degradation in Netrokona Municipal that was tested by using the Pearson product moment correlation. The result of correlation coefficient value was 0.98 where correlation is significant at the 0.01 level (2-tailed). The correlation coefficient value 0.98 indicated that there was very strong positive correlation between PDS and its effects on environment, because correlation coefficient value lies between -1 and 1 . It means that poor drainage facilities (PDFs) had impacted on the overall environment of the study area seriously. Therefore, PDFs affect the urban environment to pollute and deteriorate seriously in Netrokona Municipal. 
Table 7. Correlation between causes of PDS and effects on environment.

\begin{tabular}{llll}
\hline & & Major causes of PDS & The effects of PDS \\
\hline Major causes of PDS & Pearson correlation & 1 & $0.975^{* *}$ \\
\cline { 2 - 4 } & Sig. (2-tailed) & & 0.000 \\
\cline { 2 - 4 } & $\mathrm{N}$ & 50 & 50 \\
\hline \multirow{2}{*}{ The effects of PDS } & Pearson correlation & $0.975^{* *}$ & 1 \\
\cline { 2 - 4 } & Sig. (2-tailed) & 0.000 & 50 \\
\cline { 2 - 4 } & $\mathrm{N}$ & 50 & \\
\hline
\end{tabular}

**Correlation is significant at the 0.01 level (2-tailed).

The relation between major causes of PDS and its effects on disease occurred due to PDS is stated in (Table 8). It was found that PDS had significantly influenced disease outbreak in Netrokona Municipal that was tested by using the Pearson product moment correlation. The result of correlation coefficient value was 0.91 where correlation is significant at the 0.01 level (2-tailed). The correlation coefficient value 0.91 indicated very strong positive correlation between PDS and public health problems. Similarly, it means that PDFs had impacted on disease outbreak in Netrokona Municipal badly. Therefore, PDFs have effects on disease outbreak in the study area.

Table 8. Correlation between causes of PDS and effects on health (diseases)

\begin{tabular}{llll}
\hline & & Major causes of PDS & Disease occurred due to PDS \\
\hline $\begin{array}{l}\text { Major causes of } \\
\text { PDS }\end{array}$ & Pearson correlation & 1 & $0.911^{* *}$ \\
\cline { 2 - 4 } & Sig. (2-tailed) & & 0.000 \\
\cline { 2 - 4 } & $\mathrm{N}$ & 50 & 50 \\
\hline $\begin{array}{l}\text { Disease occurred } \\
\text { due to PDS }\end{array}$ & Pearson correlation & $0.911^{* *}$ & 1 \\
\cline { 2 - 4 } & Sig. (2-tailed) & 0.000 & 50 \\
\cline { 2 - 4 } & $\mathrm{N}$ & 50 & \\
\hline
\end{tabular}

**Correlation is significant at the 0.01 level (2-tailed).

\section{DISCUSSION}

Bangladesh is located on the tropic of cancer, so it has six seasons including the rainy season. Besides, most of the urban areas are situated in plain land or low lying areas only Chittagong Hill Tracts (CHTs) is located in elevated land. Therefore, heavy rainfall and flood is responsible for frequent flash-floods occurrence in most of the urban areas; such problem is redoubled being located in disaster prone area. Here, big cities are facing such problems acutely due to unplanned and congested construction, poor quality of construction, being densely populated, and narrowness of the existing UDS. Analogously, most of the cities in developing countries UDS are poor in quality and incapable to withdraw sudden extensive water flow (Burian, 2001; Bishop, 1968). Medium and new cities are also facing similar problems due to PDS as well as lack of appropriate monitoring and maintenance. According to, Ashley et al. (2008) adaptable urban drainage - addressing change in intensity, occurrence and uncertainty of storm water and associated studies found that capacity building is the single most important response to flood risk management.

However, Netrokona Municipal is A-class category municipal in Bangladesh that is located near to Dhaka City. Therefore, almost similar problems are seen in Netrokona Municipal which is clearly presented in (Figure 5). Here, (a) denotes narrow drainage system, (b) illegal disposal of solid waste in drain, (c) not well plastered, (d) drain water comes out road surface during heavy rainfall, (e) highly fractured, and (f) distortion of aesthetic 
environment respectively. From (Figure 5), it is stark clear that existing drainage system of Netrokona Municipal is conventional or outdated. So it is not adaptable to climate change induced situations because it can't carry sudden extreme water flow. Therefore, climate change impact; e.g. - heavy rainfall, flood, and extreme heat can create numerous environmental and health problems in urban areas of the study area. Still the urban area of Netrokona Municipal is not more construed and congested in terms of infrastructure development based on practical observation. However, still there is a chance for municipal authority to take immediately step to reconstruct the overall existing drainage system by using advance technology and facilities to confirm it's adaptable to climate change induced problems. In New Jersey, best management practices (BMPs) are designed to control runoff from the water quality storm. By designing for the water quality storm, a BMP can treat approximately $90 \%$ of New Jersey's annual storms (Berry et al., 2005). Besides, many secondary canals are not capable to carry design storms. Also, the inundation area can significantly increase from baseline to $2030 \mathrm{~s}$ and to $2050 \mathrm{~s}$ in the coastal areas of Bangladesh (Paul et al., 2013).

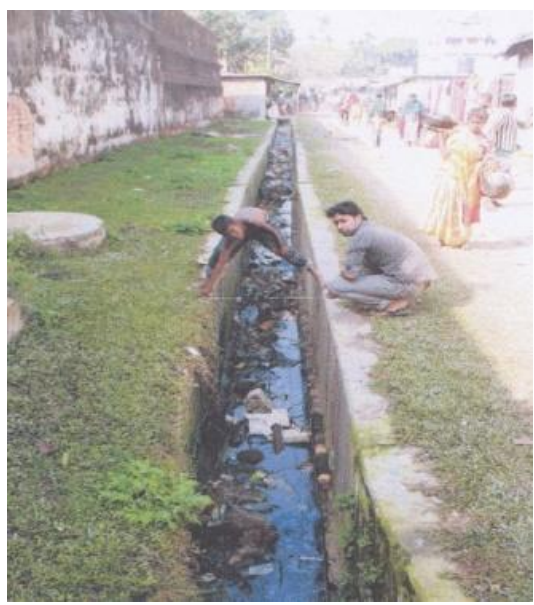

(a)

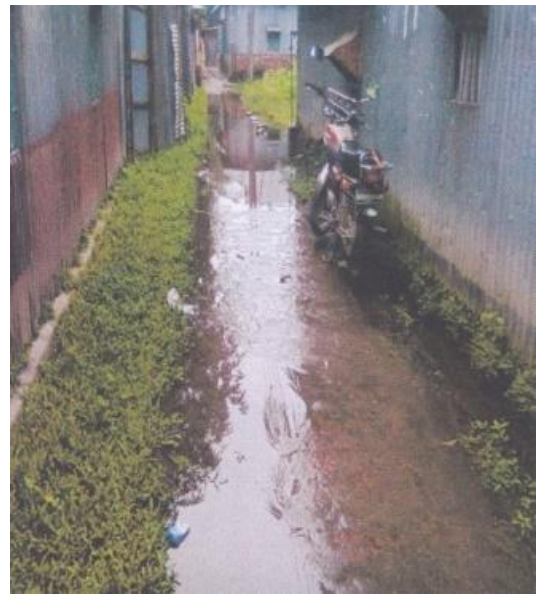

(d)

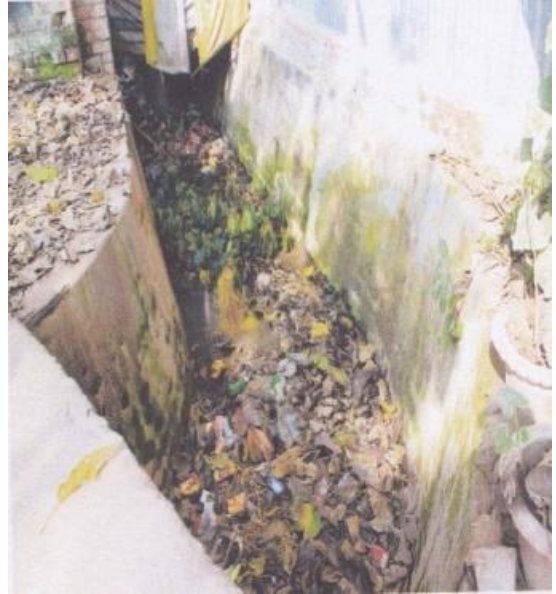

(b)

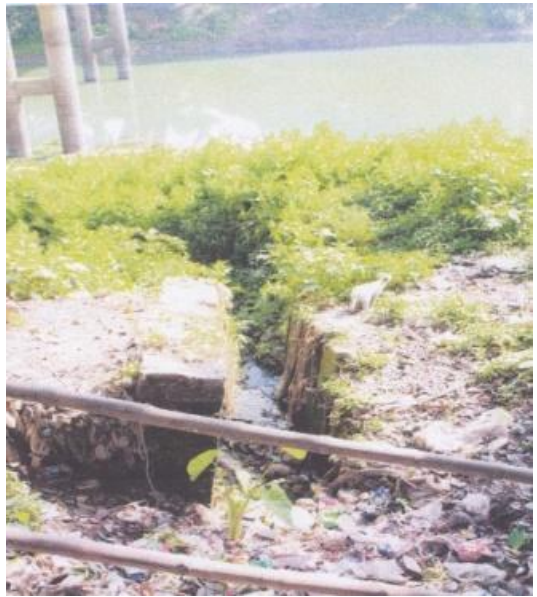

(e)

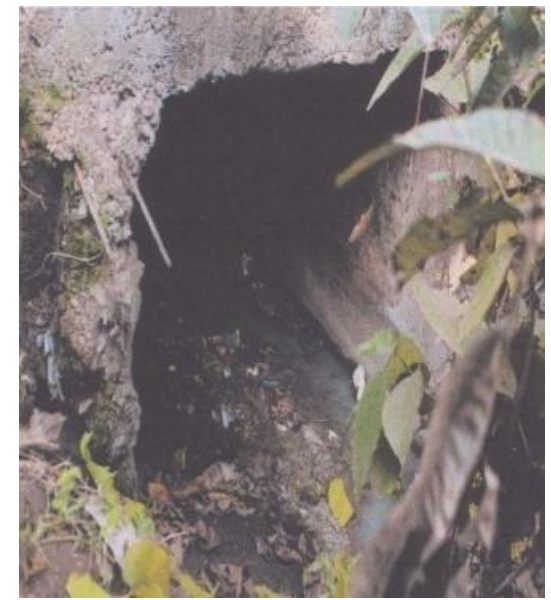

(c)

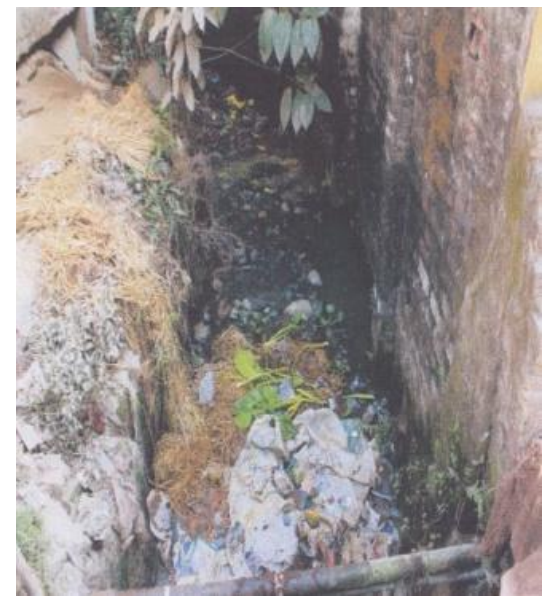

(f)

Fig. 5. Current scenarios of drainage system in Netrokona Municipal.

\section{CONCLUSION}

Netrokona Municipal is one of the fast growing Aclass municipal in Bangladesh. Its infrastructure development within urban areas is leading to flash- floods and damage of available road systems. Consequently, the urban environment is deteriorating as well as creating manifold problems; e.g. - public health hazards, unstable development, 
and unsustainable environment. The overall situation of current UDS of Netrokona Municipal is quite unsatisfactory. Further, it is not fitting to cope with adverse natural calamities viz. heavy rain falls and flood, where climate change induced impact is redoubling such situations. In addition, the constructed drainage system is not suitable to adapt with climate change impacts (e.g., heavy rainfall \& floods). Therefore, existing PDS is one of the most responsible factors for environmental damage as well as making all development activities unsustainable. However, adverse effects can be minimized if the concerned authority takes appropriate steps immediately.

\section{ACKNOWLEDGMENT}

This study was done as partial fulfillment of Master's Degree in Environmental Science of Institute of Forestry and Environmental Sciences (IFES), University of Chittagong, Bangladesh. Concluding the works, we would like to express our deepest gratitude to them who cordially supported us to make fruitful the entire study by providing data and analysis.

\section{REFERENCES}

Ahmed, M. F. and Islam, M. S. (2014). Urbanization and environmental problem: An empirical study in Sylhet City, Bangladesh. Research on Humanities and Social Sciences, 4 (3): 161-172.

Alam, O.; Hossain, M. M. and Hossain, A. Kh. M. E. (2013). Climate change adaptation and healthcare waste effect on it in Chittagong Metropolitan area of Bangladesh. International Conference on Climate Change Impact and Adaptation (I3CIA-2013), DUET, Gazipur, Bangladesh, pp. 525-535.

Alberta Environment (1999). Storm water management guidelines for the province of Alterta. Available at https://alidp.org/ knowledgebase/article/stormwatermanagement-guidelines-for-the-province-ofalberta.

Alom, M. M. and Khan, M. Z. H. (2014). Environmental and social impact due to urban drainage problems in Dhaka City, Bangladesh. International Journal of Engineering and Advanced Technology, 3 (6): 128-132.
American Public Works Association (APWA). (1976). History of public works in the United States: 1176-1976. Chicago, IL.

Apirumanekul, C. and Mark, O. (2001). Modelling of urban flooding in Dhaka City. $4^{\text {th }}$ Danish Hydraulic Institute (DHI) Software Conference, Helsingør, Denmark, pp. 101108.

Arisz, H. and Burrel, B. C. (2006). Urban drainage infrastructure planning and design considering climate change. Available at https://www.glisaclimate.org/resource/urbandrainage-infrastructure-planning-and-designconsidering-climate-change.

Asaduzzaman, M.; Islam, M. Z. and Chowdhury, S. (2014). Solid waste management and drainage facility concerns in the real estate management: A study on Dhaka City. Banglavision, 13 (1): 101-116.

Ashley, R.; Blanksby, J. and Cashman, A. (2008). Building knowledge for a changing climate (BKCC) adaptable urban drainage addressing change in intensity, occurrence and uncertainty of stormwater (AUDACIOUS). Available at http://cdn. environment-agency.gov.uk/scho1009brbi-ee.pdf.

Asian Development Bank (ADB) (2011). Technical assistance report: Strengthening the resilience of the urban water supply, drainage, and sanitation to climate change in coastal towns in Bangladesh. Financed by the Japan Fund for Poverty Reduction, Project Number: 45519, pp.15.

Ashraf, M. A. and Chowdhury, M. S. A. (2009). Drainage planning in the cities of Bangladesh: Case study of drainage and water logging in Chaktai Commercial Area, Chittagong. Journal of Bangladesh Institute of Planners, 2: 49-60.

Bangladesh Bureau of Statistics (BBS) (2011). Population and housing census 2011, socioeconomic and demographic report, National series, volume-4, Statistics and Informatics Division (SID), Ministry of Planning, Bangladesh.

Bangladesh Bureau of Statistics (BBS). (2013). District statistics 2011: Netrokona. Statistics and Informatics Division (SID)Ministry of Planning, Government of the People's Republic of Bangladesh. 
Banglapedia (2006). National encyclopedia of Bangladesh. Asiatic Society, Dhaka, Bangladesh.Available at https://.en. banglapedia.org/index.php?title=Netrokona District.

Bari, F. M. and Hasan, M. (2001). Effect of urbanization on storm runoff characteristics of Dhaka City. Tsinghua University Press. XXIX IAHR Congress. Beijing.

Berry, D.; Bhandari, K.; Yates, K.; Donnelly, J.; Avery, M. and Vilere, M. (2005). Engineered storm water management for low-income urban communities. A design proposal and plan for implementation and educational outreach, Proposal \#: G4S70481

Bishop, M. (1968). The Middle Ages. Houghton Mifflin Company, Boston.

Burian, S. J. (2001). Developments in water supply and wastewater management in the United States during the $19^{\text {th }}$ Century. Water Resources Impact, 3 (5): 14-18.

Chowdhury, J. U. and Islam, G. M. T. (2005). Hydrological and drainage study of the development proposal of Uttara Residential Model Town, Client: RAJUK (Capital Development Authority), Dhaka.

Coterell, A. (1980). The encyclopedia of ancient civilizations. Rain bird Publishers, 176-178. Available at https://trove.nla.gov.au/work/ 9270349.

Hossain, M. M.; Alam, O. and Uddin, M. S. (2013). Geographic distribution of health care entities in Chittagong Metropolitan area in relation to our quest for a climate adaptive healthcare waste management system. International Conference on Climate Change Impact and Adaptation (I3CIA-2013), DUET, Gazipur, Bangladesh, pp.505-5016.

Huq, S. and Alam, M. (2003). Flood management and vulnerability of Dhaka City. Bangladesh Center of Advance Studies (BCAS), Dhaka.

Islam, N. (1999). Urbanization in Bangladesh and the growth of Dhaka: Landuse, poverty, and governance. $K P$ Bagchi \& Company. Calcutta.

Islam, T. (2003). Environment Bangladesh: Poly bags Add To Flood Woes. IPS World News. Dhaka.

Jahan, M. (2012). Impact of rural urban migration on physical and social environment: The case of Dhaka city. International Journal of
Development and Sustainability, 1 (2): 186-194.

Khan, D. M.; Shams, K. and Hossain, M. K. (2012). Climate change impact on urban drainage in coastal belt of Bangladesh. $9^{\text {th }}$ International Conference on Urban Drainage Modelling Belgrade.

Kirby, R. S. and Laurson, P. G. (1932). The early years of modern civil engineering. Yale University Press, New Haven, CT, pp. 2272399.

Kjellstrom, T.; Friel, S.; Dixon, J.; Corvalan, C.; Rehfuess, E.; Campbell-Lendrum, D. et al. (2007). Journal of Urban Health: Bulletin of the New York Academy of Medicine, 84 (1): 86-97.

Laskar, S. I. (1996). Urbanization in Bangladesh: Some Contemporary Observations. Bangladesh Development Study, 24 (1-2): 207-216.

Local Government Engineering Department (LGED) (2015). Final initial examination report, BAN: Third urban governance and infrastructure improvement (Sector) Project Netrokona drainage subproject (Phase 1) UGIIP-III/I/NETR/DR/01/2014.

Mcdonough, W. and Braungart, M. (2002). Cradle to cradle: remarking the way we make things. North Point Press, a Division Farrar, Straus and Giroux, 19Union Square West, New York 10003, ISBN 0-86547-587-3.

McInerney, B. and Magar, R. T. (2014). Urban environmental challenges and poverty alleviation, Bangladesh.

Mowla, Q. A. and Islam, M. S. (2013). Natural drainage system and water logging in Dhaka: Measures to address the problems. Journal of Bangladesh Institute of Planners, 6: 23-33.

Parkinson, J. (2003). Drainage and storm water management strategies for low-income urban communities. Environment \& Urbanization, 15 (2): 115-126.

Paul, S.; Islam, A. K. M. S.; Islam, G. M. T.; Shopan, A. A. and Bala, S. K. (2013). Impact of climate change on urban drainage systems in three selected coastal towns of Bangladesh. International Conference on Climate Change Impact and Adaptation (I3CIA-2013), DUET, Gazipur, Bangladesh, pp. 397-406.

Pidwirny, M. (2006). Causes of climate change. Fundamentals of Physical Geography $\left(2^{\text {nd }}\right.$ 
Ed). Available at https://www.physicalgeo graphy.net/fundamentals/7y.html.

Rana, M. M. P. (2011). Urbanization and sustainability: challenges and strategies for sustainable urban development in Bangladesh. Environment, Development and Sustainability, 13 (1): 237-256.

Sarkar, S. (2012). Netrokona district. In Sirajul Islam and Ahmed A. Jamal. Banglapedia: National Encyclopedia of Bangladesh (Second ed.). Asiatic Society of Bangladesh.

Shakir-R-Rahi, M. (2011). Waste disposal and management in Netrokona Municipality Area. Master's Thesis, Department of Environmental Science, Bangladesh Agricultural University, Mymensingh.
Shamsuddoha, M. and Chowdhury, R. K. (2007). Climate change impact and disaster vulnerabilities in the coastal areas of Bangladesh. COAST Trust and Equity and Justice Working Group (EJWG).

Taleb, M. A. (2012). Comparative study of urban area extension and flood risk in Dhaka City of Bangladesh. Global Journal of Human Social Science Geography \& Environmental Geosciences, 12 (11): 37-40.

Tawhid, K. G. (2004). Causes and effects of water logging in Dhaka City, Bangladesh. TRITALWR unpublished Master Thesis, Royal Institute of Technology, Stockholm.

Zumrawi, M. M. E. (2014). The impacts of poor drainage on road performance in Khartoum. International Journal of Multidisciplinary and Scientific Emerging Research, 3 (1): 901-907. 